\title{
Social Security and Gender Justice in South Africa: Policy Gaps and Opportunities
}

\author{
SOPHIE PLAGERSON*, TESSA HOCHFELD** AND LAUREN STUART ${ }^{* * *}$ \\ * Centre for Social Development in Africa, University of Johannesburg, PO Box 524, \\ Auckland Park, 2006, South Africa \\ email: splagerson@uj.ac.za \\ ** Centre for Social Development in Africa, University of Johannesburg, PO Box 524, \\ Auckland Park, 2006, South Africa \\ email: tessah@uj.ac.za \\ *** Centre for Social Development in Africa, University of Johannesburg, PO Box 524, \\ Auckland Park, 2006, South Africa \\ email: laurens@uj.ac.za
}

\begin{abstract}
If gender is neglected in the design and implementation of mainstream social welfare models, unequal social and economic outcomes for men and women tend to be reproduced. This paper contributes to debates about how social protection can contribute to promoting gender equality by considering the gendered redistributive and transformative effects of three types of social security instruments in South Africa: social assistance, unemployment insurance and public employment programmes. All the instruments have some pro-poor and gendered design innovations. The Child Support Grant has had better outcomes than the other instruments, but redistributive and transformative gender effects across the social security spectrum are disappointing. Limited social transformation is largely due to implementation inefficiencies and unresponsive institutions. To serve both economically redistributive and socially transformative ends, gender-sensitive synergies between social security instruments and with other multisectoral interventions could be strengthened, such as access to social services (especially quality child care) and access to basic services (such as water, electricity, transport and internet services).
\end{abstract}

\section{Introduction}

Gender and social security policy are linked through the design of policy instruments, their implementation and their social and economic outcomes (Fultz and Francis, 2013). Social security measures interact with gender-specific vulnerabilities and risks exacerbated by gender inequalities in several ways: more women than men experience poverty; women represent a growing proportion of the labour force yet, on average, receive lower wages in more insecure environments than men; and women bear the greatest personal cost of care and carry a disproportionate share of the responsibilities in the domestic sphere compared to men. 
If gender dynamics are neglected, social welfare systems may disregard how policy casts men and women into certain social roles, and may perpetuate gender inequalities (Patel, 2018, forthcoming). Conversely, gender-sensitive social security may redress inequalities, and play a role in redistributing care responsibilities and recognising and valuing unpaid work (ILO, 2017). The 2015 United Nations Sustainable Development Goals explicitly promote social protection as a vehicle for achieving not only human development, but also improved gender equality outcomes (UN, 2015).

This article offers a fresh look at gender and social protection in South Africa, through a social justice lens which views redistribution and transformation as necessary for justice to be fully realised. The South African socio-economic landscape and its intersection with social security policies provide valuable insights with international relevance. Many developed and developing countries, across a broad spectrum of legal, political and social contexts, are grappling with issues of reconciling work and care policies (Razavi and Staab, 2012; Yerkes, 2014). In this article, social security is understood as public measures designed to protect individuals and families against income insecurity caused by contingencies such as unemployment, employment injury, maternity, sickness, invalidity, old age and death in the form of social insurance, social assistance and other measures. Social protection is a broader notion, incorporating social security provided by the state, as well as other programmes and instruments, including informal and community protection systems, social services, and developmental social welfare.

The South African national context is characterised by high levels of unemployment, poverty, and deep-seated gender inequalities with regard to women's earnings, access to labour markets, and exceptionally high levels of violence against women. South Africa's social welfare model uses a set of social protection policies to protect citizens from the worst vagaries of poverty and is informed by a progressive constitution which regards gender equality as critical to the attainment of social justice. In order to assess gendered and poverty alleviation outcomes of social protection, three areas of social security are examined: the Child Support Grant (CSG) as an example of social assistance; the Unemployment Insurance Fund (UIF) as an example of social insurance; the Social Sector division of the Expanded Public Works Programme (EPWP) as an example of a public works programme. We argue that, while these programmes are all trying to address poverty in pro-poor, redistributive ways that pay attention to the inequities of the past, including gender, key provisions that could enable women to bridge their private and public roles, such as quality childcare or basic services including water or internet services, are often not guaranteed.

In the next section, we outline the theoretical framework and our approach to the analysis. We then provide an overview of social security in South Africa, and an analysis of the three examples of social security in terms of their gendered redistributive and transformative effect. The paper concludes with a reflection 
on the relative and collective contribution of social security programmes to redistribution and transformation from a gender perspective.

\section{Economic redistribution and social transformation}

Redistributive outcomes are those that reduce income and opportunity inequality within a population and between groups. Transformative outcomes are those that realise human rights, 'empowering those in need both economically and politically, and rebalancing power asymmetries in society' (UNRISD, 2016: 61).

The analysis of social security in terms of redistributive and transformative outcomes for women is underpinned by a social justice perspective. Nancy Fraser's approach to social justice can be usefully applied to the study of social security. She argues that both distributive justice (in terms of a more equitable distribution of resources) and recognition justice (personal and social dignity) need to be present for justice to be fully realised (Fraser, 1995). This view builds the understanding of poverty as not only having material but also relational dimensions (Devereux and McGregor, 2014). By acknowledging the intrinsic value of redistribution and recognition, a social justice approach does not simply accommodate trade-offs between social and economic outcomes but affirms that social justice is achieved in social protection when 'welfare beneficiaries do not have to choose between their sense of dignity and their need for material assistance' (Hochfeld and Plagerson, 2011: 53).

With regard to redistributive outcomes of social security, we report on findings which have been disaggregated by gender, in relation to access to social security, poverty and inequality levels, access to labour markets and other redistributive programmes. To assess the socially transformative impact of social security instruments, we seek to determine whether these can act as catalysts for long-term change through increased recognition of women, through integrated support for women's productive and reproductive roles, and through transformation of gender relations (Molyneux et al., 2016).

The notion of care (whether paid or unpaid) is crucial to a gender-sensitive framework for the analysis of both economic and social outcomes of social security. Care work refers to physical care (such as house work, and care for children and older persons), as well as the provision of emotional care and social support. Strong views are held in society about the appropriateness of gender divisions in care, and women tend to bear the greatest care burdens. The distribution of care responsibilities across the household, markets, the public sector and the voluntary sector is central to social well-being and to patterns of employment and economic development (Razavi, 2007). A gendersensitive framework examines how the design and implementation of social security programmes either reinforce women's and men's traditional roles and responsibilities and exacerbate existing inequalities, or harness the potential 
for social protection to contribute to a transformation of gender relations in economic and social spheres (Holmes and Jones, 2013; Luttrell and Moser, 2004).

\section{Social security in South Africa}

Internationally acclaimed, the South African Constitution promotes and protects social and economic rights, and gender equality (R.S.A., 1996). It legislates for the right to social security to be progressively realised by the state, subject to the availability of resources. Social security provisions in South Africa have transformed the previously discretionary and discriminatory social policy framework of the apartheid regime. Key elements of the social protection system include:

\section{Social assistance}

Social assistance is non-contributory and tax-funded. It targets the poorest and most vulnerable groups in society - primarily older persons, persons with a disability and children. The South African government distributes more than 17 million unconditional cash transfers, reaching over a third of the South African population (SASSA, 2017).

\section{Social insurance}

Social insurance schemes are contributory and primarily linked to formal sector employment. Public social insurance includes the Unemployment Insurance Fund (UIF). Contributions by employers and employees are compulsory for all employees in formal employment. However, there is no compulsory social insurance to cover pension and medical benefits (Woolard et al., 2011).

\section{Public employment programmes}

Public employment programmes provide a limited number of 'statesponsored employment for the working-age poor who are unable to support themselves due to the inadequacy of market-based employment opportunities' (McCord, 2012: 8). The Expanded Public Works Programme (EPWP) was established in 2004 as one response to a lack of employment growth and to harmonise a host of smaller public works programmes into one large national push for creating job opportunities. Work is temporary (with the exception of the Community Work Programme) and paid via small stipends. In South Africa the EPWP functions like a social security mechanism, although globally public employment is considered a labour market intervention (Meth, 2011).

\section{Other social protection services}

Within a wider social protection strategy, the interventions listed above are complemented by several others, including basic education, free primary health care, school nutrition, housing, basic municipal services and welfare services. 
While these services are not the focus of this study, it is important that future research investigates the gendered effects of these programmes, and of the social package as a whole.

In the sections that follow, we look in turn at how three social security programmes are differentially related to the wellbeing and empowerment of women and men.

\section{The Child Support Grant}

\section{Overview}

The CSG is a publicly-funded means-tested monthly cash transfer, reaching more than 60 per cent of children, or over 12 million children each month (SASSA, 2017). The CSG was introduced in 1998 by the first democratic government of South Africa. Access to the grant has since been substantively scaled up and extended. The age threshold has been gradually raised from 7 to 18 years, the means test was revised in 2008 to be calculated at 10 times the grant amount (substantially extending eligibility), and the value of the grant, while modest, has risen marginally above inflation and is equivalent to USD26 (as of April 2017).

The CSG was designed to be gender-responsive and relevant to the realities and challenges of households in South Africa where mothers are not always able to live with the child, for instance due to the need to migrate for work, or high levels of HIV/AIDS leading to orphan-hood. The designated recipient of the CSG is the child's primary caregiver, who may be male or female and who is defined as the person that takes primary responsibility for meeting the daily care needs of the child.

The CSG is a rights-based entitlement and was designed to be redistributive. It was explicitly intended to contribute to the well-being of young children (primarily their food requirements) who were among the poorest and most vulnerable groups in the society (Lund, 2008).

\section{Is the CSG gender-redistributive?}

The majority (98.1 per cent) of CSG recipients are women (mothers, grandmothers or other female caregivers) (SASSA, 2014) although, in terms of child beneficiaries, the numbers are evenly split between girls and boys (Brockerhoff, 2013). Low engagement of men in care-giving is reflected in the low take-up of the CSG by male caregivers (Khan, 2018, forthcoming; Patel, 2017).

Social grants (especially the CSG) have had a substantial impact on the incidence and depth of poverty and inequality. The CSG effectively targets the poorest, and increases the incomes of the bottom income decile by almost four times (Inchauste et al., 2015). If social grants were not available, income inequality in 2010, as measured by the Gini coefficient, would have been substantially higher at 0.74 instead of 0.69 . In particular, female-headed households would 
have experienced much higher levels of inequality in the absence of social grant income (Bhorat et al., 2013b).

The receipt of social grant income has been effective in ensuring women's access to resources, especially in female-headed households (Patel, 2017). Increased income through grants is also associated with higher likelihood of having bank accounts, life insurance and some form of savings (Delany et al., 2008). However, this has not been sufficient to overcome the poverty gender gap and poverty still remains a gendered phenomenon (Posel and Rogan, 2012).

Only 13 per cent of CSG recipients have employment with a regular wage (Patel et al., 2017). Despite structural barriers to women's employment, there are indications that the relatively small Child Support Grant is associated with a higher probability of female participation in the labour force (Eyal and Woolard, 2011; Leibbrandt et al., 2013). The findings are in contrast with common fears that social grants create dependency (Williams, 2007). While grants are primarily spent on food and children's basic needs, evidence also suggests that they can enable individuals to subsidise childcare costs; to finance and alleviate constraints to job search; to fund small enterprise creation; and improve productivity through better health, nutrition, and training (Devereux et al., 2011; Williams, 2007).

The redistributive and poverty-reducing potential of the CSG has been limited by poor linkages with other strategies that can enhance the wellbeing of women and alleviate some of the burdens in the domestic sphere, such as increased access to quality child-care services and broader access to social insurance. Deliberate communication and administrative efforts could connect grant beneficiaries with existing poverty reduction programmes related to water, sanitation, electricity, food security and internet services (Patel, 2018, forthcoming).

\section{Is the CSG gender-transformative?}

Dignity is a common theme in the narratives of beneficiaries, who feel validated in their personal, caring and social roles as a result of the CSG, demonstrating a close relationship between economic redistribution and human dignity in the lived experiences of grant recipients (Hochfeld and Plagerson, 2011). Beyond the confines of the household, the CSG has been associated with increased capabilities to fulfil societal roles, and to embrace active citizenship through participation in burial societies, savings groups, community forums and engagement with political processes (Plagerson and Ulriksen, 2015).

Yet the CSG is also associated with gender discrimination that has negative impacts on social recognition. Negative discourses are common in the media and within beneficiary communities that construct women as self-serving and a drain on resources, despite the evidence that show its poverty-alleviating effects (Surender et al., 2010). These include concerns that CSGs incentivise childbirth, 
and more generally about a lack of responsibility amongst young mothers for their children and inappropriate use of the grants for personal consumption (Hochfeld and Plagerson, 2017). However studies investigating these claims have found no evidence of widespread perverse incentive effects of social grants but show that the vast majority of mothers use the grant in ways that are beneficial for their children and households (Makiwane, 2010; Rosenberg et al., 2015). Nonetheless, these discourses can undermine beneficiaries' and children's rights to social assistance, and may stigmatise women for relying on grants, engendering a lack of cultural and social value for them despite their substantial social contributions via both informal productive labour and unpaid caring work (Hochfeld and Plagerson, 2017).

As indicated in the previous section, the CSG does have multiple benefits that accrue directly to women both in their reproductive and productive roles. CSG recipients typically manage the grants and report relatively high levels of financial decision-making autonomy (Delany et al., 2008; Patel et al., 2015). The CSG supports recipients' economic independence within the household, enabling women to allocate financial resources for their preferred welfare-related and income-generating goals (Patel and Hochfeld, 2011; Patel et al., 2015).

Yet, a transformative analysis suggests that the feminisation of social grants does not automatically overcome the challenges that women face in bridging their double roles as poorly rewarded carers and productive economic agents (Plagerson and Ulriksen, 2015; Sabates-Wheeler and Roelen, 2011). The grant recognises women's care-giving role but at the same time reinforces traditional divisions of labour. In practice, male caregivers struggle to access the grant and officials assume that it is for female caregivers (Khan, 2018, forthcoming). Critics from a gender perspective also underline the instrumental way in which women beneficiaries are constructed as conduits for child well-being (Molyneux, 2007). A lack of a fundamental shift in gender relations is confirmed by the changing patterns of childcare, redistributed between women within the extended household and across generations, rather than between men and women. Overall, the CSG has not served to significantly shift the boundaries and social expectations around care responsibilities. These expectations constrain women's ability to access and maintain their position in the labour market.

\section{Unemployment Insurance Fund Overview}

The Unemployment Insurance Fund (UIF) pays benefits in the event of unemployment, illness, maternity, the adoption of a child and death (by assisting family members of the deceased) (Mpedi and Fourie, 2008). Almost 1.6 million employers and 9 million employees are registered with the UIF (R.S.A., 2015). The UIF is financed by the monthly contributions of employers and employees 
(Bhorat et al., 2013a). The benefit amount is dependent on the claimant's wage level prior to applying for unemployment benefits and the previous length of time in employment. Maternity benefits can be claimed for a maximum period of 17.29 weeks. To gain maximum credit for the full period of maternity pay it is necessary to have worked continuously for four years (R.S.A., 2015).

The primary focus of the UIF is on the formal employment sector (where males are over-represented) and on the segment of the unemployed who have previously been employed (Bhorat et al., 2013a). The UIF excludes self-employed workers and employees who work less than 24 hours per month. In practice, less than 5 per cent of the unemployed receive unemployment benefits (NPC, 2011). Efforts to expand UIF coverage led to its extension in 2003 to domestic workers (including those working for multiple employers) and to seasonal workers (predominantly women).

\section{Is the UIF gender-redistributive?}

In a context of high unemployment, the UIF system has the potential to play a key role as the only public social insurance programme in South Africa that caters to the unemployed (Bhorat et al., 2013a). The Fund has a poverty alleviation mandate, and aims to alleviate the social and economic costs of unemployment (NPC, 2011). However, the redistributive role of the UIF is still confined to a small sub-section of the unemployed. This leaves many vulnerable groups excluded such as those who have never worked as formal employees before and many of those in the informal sector, in which women are over-represented.

Amendments introduced in 2003 were favourable to women since they provided for higher payments to lower income workers. However, this did not address the underlying issue of the under-representation of women as contributors and claimants. In the fourth quarter of 2017, more men (64 per cent of male employees) reported contributions to the UIF than women (54 per cent of female employees) (SSA, 2018). In relation to claimant behaviour, females are further under-represented. Women have become more disadvantaged with time since their representation ratio (ratio of female-to-male claimants including for maternity benefits over the ratio of female-to-male contributors) has declined from 0.99 in 2005 to 0.75 in 2011 (reaching its lowest point during the financial crisis in 2009-2010). The disparity between men and women in terms of access to the UIF and claim behaviour may result from women's over-representation in part-time, low-income, intermittent and precarious jobs, and thus fewer credit days with which to claim unemployment benefits (Bhorat et al., 2013a).

Both men and women contribute an equal proportion of their salaries to UIF, but men cannot claim maternity benefit. This implicitly acknowledges women's reproductive role in society. The UIF provision of maternity benefits has benefited a growing number of women in formal employment (and a small segment of women in informal sectors). Take-up of UIF maternity benefits has increased 
over time, from 81,000 claims in $2005 / 6$ to 98,631 in $2016 / 17$. In monetary value, maternity claims represent 11 per cent of all UIF benefits disbursed (R.S.A., 2017). Yet, available evidence indicates that the reality experienced by women remains precarious. Research has shown that the bureaucracy involved in accessing maternity benefits is complicated, with long delays in the disbursement of claimants' maternity benefits. This drastically undermines the potential benefits of the money. If benefits are not received during the maternity period, mothers may not be able to remain on leave or may suffer as a result. Further financial pressures may occur as a result of the maternity benefit being smaller than a woman's salary, increasing the chance of mothers not taking the full four months to which they are entitled (Boswell and Boswell, 2011). Recent changes to the law may improve these limitations: women may now apply eight weeks before the child is due and 12 months after birth; maternity benefits rates have been increased from a sliding scale of 38-60 per cent to a fixed rate of 66 per cent of the (female) contributor's earnings; maternity benefits have been de-linked and do not detract from a woman's ability to claim for other benefits and maternity benefits are available in the case of miscarriage in the third trimester (Department of Labour, 2016).

The proportions of (almost exclusively female) domestic workers covered by UIF contributions showed a large increase in the 18 months following their inclusion, albeit from a low base. Steady increases in the numbers of registrations of domestic employers have continued to occur, and a recent report showed that 667,300 domestic workers were registered with the UIF in March 2016 (66.1 per cent of domestic workers) (R.S.A., 2015). Nonetheless, many remain unregistered, primarily due to widespread non-compliance by employers (Malherbe, 2013). Unemployment benefits payable upon dismissal are particularly necessary in the context of the job insecurity with which many domestic workers are faced. While there are provisions for domestic workers who lose one of their jobs to claim partial unemployment benefits, the low wages in this sector mean that the amount of benefit to which they are entitled may be too limited to provide any meaningful level of income security.

There are some provisions that complement maternity leave provisions, such as Child Support Grants for the children of caregivers earning less than the means test threshold. There is some provision for childcare through subsidies to the Early Childhood Development sector but, in general, the care of children under the age of three is considered the responsibility of parents and extended families, private institutions and non-governmental organisations (Mokomane, 2011). In terms of social security as a whole, provision for domestic workers remains patchy, given the exclusion for example from access to the Compensation for Injuries and Diseases Act (COIDA). These complementary interventions remain fragmented and, as this section has shown, women face disproportionate challenges in accessing labour markets and social insurance. 


\section{Is the UIF gender-transformative?}

Changes in legislation have mainly been in the direction of greater inclusivity, with some recognition of the implications for legislation of gender equality considerations. The right to maternity leave and maternity benefits is integral to the intersection of women's care and economic roles in society and has important implications for the social and economic well-being of women. Relevant legislation and the availability of maternity benefits for mothers registered with the UIF represent an important recognition of working mothers, and their combined productive and reproductive roles. While maternity benefits are institutionally problematic (such as delays and difficulties in claiming) and do not extend to cover nearly enough women (as they often have not contributed enough to receive full benefits), it is an important mechanism which can have symbolic and substantial value for women. Yet, these provisions remain confined within a narrow paradigm of assistance to women. They are provided as a social right to women in employment rather than as a universal right to all women and are primarily designed to protect the health of the mother (and child) rather than to enhance women's social rights through a holistic approach to work/family balance and gender equality considerations. For example, the amendment introduced in 2016 includes a clause that women must have worked for 13 weeks prior to submitting a maternity benefits claim. In a context of increasing feminisation of the labour market, and despite broad acceptance of women entering the workplace, traditional attitudes towards gender role division within the household persist and are echoed by current policy approaches (Gordon et al., 2012).

The inclusion of domestic workers in the UIF is progressive and provides a precedent for extending insurance to the informal sector (Dinkelman et al., 2014). However, the data also shows that, for transformative outcomes to be achieved, complementary interventions such as improved access to quality child care are necessary as well as efforts to reduce administrative barriers, to counter discrimination against women in the workplace and to increase employer compliance with legislation (on contracts, wages and conditions of employment) (Malherbe, 2013).

\section{Expanded Public Works Programme (Social Sector) Overview}

In policy terms, the EPWP has an important role of 'contributing to the social security net and to community development, and possibly as a stepping stone to formal employment or self-employment' (Vaughan, 2016: 12). The EPWP in South Africa operates in four distinct sectors, of which the social sector is one. The social sector (EPWP-SS) was mandated specifically to provide job opportunities for women, and provide an important service that had women and children 
as its primary beneficiaries (Parenzee and Budlender, 2015; Skosana, 2013). The work opportunities that the EPWP-SS provides are in the delivery of social development and community protection services, with a primary emphasis on Early Childhood Development (ECD), such as pre-school and day care facilities for young children, and Home and Community Based Care (HCBC), which is the delivery of home-based basic health services within communities, such as administering medication and assisting with the personal hygiene of persons with illness or disabilities.

The inclusion of the social sector as a key division of the EPWP is unusual and innovative globally (Antonopoulos, 2009; Parenzee and Budlender, 2015) as public works internationally are largely dominated by infrastructure projects, especially road construction and maintenance. Its conception recognises that care work is not only confined to the private sphere of the home but also contributes to filling public infrastructural gaps and mitigating service delivery failures in the health, social welfare and education sectors (Razavi, 2011). Below, we argue that, as far as we can tell by using the only available data on the EPWP which is severely limited and of poor quality (EPRI, 2015), the redistributive and transformative gendered outcomes have been weak.

\section{Is the EPWP-SS redistributive (for women)?}

As the EPWP-SS specifically engages with the gendered expectations of care work as a means to engage and benefit women, it has been successful in including women as participants. In 2012, 85 per cent of the participants in the social sector were female (Vetten, 2015). This is a higher percentage than in any of the other sectors, and higher than the quota for women participants, originally set at 60 per cent but subsequently lowered. However, some have criticised the reinforcement of gendered care roles in this sector and the use of an already female-dominated field to increase women's EPWP participation (Parenzee and Budlender, 2015).

One area of moderate success is that, overall, by targeting people living in poverty including women, youth and people with disabilities, the EPWP-SS stipend has provided some poverty relief to participant households. Researchers have estimated that the programme is associated with a reduction in EPWP-SS participants living below the food poverty line from 55 to 40 per cent (EPRI, 2015). In the same study, participants indicated that their stipends 'put food on the table' (p.39) This is an important achievement as the EPWP in South Africa has been designed, at its most fundamental, as a programme to protect people from the worst consequences of structural unemployment (Vaughan, 2016).

Nonetheless, stipends in the EPWP-SS remain unacceptably low. In addition to the consequent daily survival struggles, the building up of social or financial assets which will have positive longer term effects for participants is impracticable at this level of pay. The stipends across the EPWP vary from more than the minimum wage of R88/ day (USD6.5) stipulated in the EPWP ministerial 
dispensation (Mahlakoana, 2017), to far below this minimum, indicating a persistent lack of compliance by implementing departments and their partner organisations on conditions of employment in the EPWP (EPRI, 2015). The lowest EPWP wages are in the social sector, followed by the non-state sector, which includes NGO care services. This contrasts with the infrastructural sector wages, paid at far over minimum levels (Vetten, 2015).

The poor redistributive outcomes are compounded by serious underfunding and weak resourcing administration, with direct gendered effects. Payments made to NGOs or ECD centres are often delayed by months, creating financial stress for the participants. Precisely because the sector participants are largely female, the major implementation problems disproportionately affect women and the families they support. Similarly, NGOs are regularly not given sufficient notice about future funding. This results in a perpetual state of uncertainty, leading to institutional insecurity which has knock-on effects for participants and potentially lowers service quality due to a demoralised workforce. While EPWP-SS funding was intended to cover trainee or new workers, the problem of substitution has been noted in that posts previously paid a salary were migrated to EPWP to reduce costs to NGOs (Vetten, 2015). These and other widely reported administration problems are a critical weakness in the EPWP-SS and appear to be qualitatively worse than in the other sectors (EPRI, 2015; Vaughan, 2016; Vetten, 2015).

The likelihood of finding secure, decently paid employment post-EPWP-SS participation is slim (van der Westhuizen, 2015). This is due to the presence of similarly trained workers in an underfunded field with few vacancies; a challenge that all sectors of the EPWP face but one that has been particularly noted in the ECD sector. Even where employment is found, the insecure working conditions and low wages on the open labour market in the ECD, HCBC, and other social sector fields, almost guarantee that those working join the ranks of the working poor (Vetten, 2016). There are few existing care organisations in rural areas, where the needs are greatest and where there is a huge lack of employment opportunities for women (Jacobs et al., 2010).

With regard to cross-policy linkages, EPWP workers are in theory eligible for unemployment insurance but, in 2015, the rate of compliance with UIF was estimated at only 50 per cent (Butler and Cartwright, 2016) and therefore half of EPWP workers are excluded from benefits as no contributions have been made on their behalf. EPWP workers are eligible for public health services, state Old Age Grants, and the CSG yet, if they meet means-test criteria, their participation in the public works programme does not smooth access or reduce the need for negotiating administrative hurdles, even where, for example, means testing is repeated by different agencies.

The redistributive gendered effects of the EPWP-SS are therefore minimal. The low stipend for the period of participation and some training in ECD and 
$\mathrm{HCBC}$ are the only redistributive benefits. No mechanisms are in place to offer women more income security, a chance to build financial or productive assets over time, or the possibility of finding work post-participation.

\section{Is the EPWP-SS gender-transformative?}

The EPWP-SS is inherently gendered, as the care services it provides are traditionally located in women's sphere of activity. The participants themselves are primarily women, and the services to users mostly benefit women as they shoulder the burden of private and community care in the absence of public or publicly subsidised care services (Razavi, 2011). The simultaneous creation of work and the delivery of social services, frequently in the same communities, is an example of integrative social policy in action. The potential to doubly benefit women as workers and beneficiaries has been heralded as having the potential to contribute significantly to improving gender equality (Antonopoulos, 2009).

The programme does increase the visibility of care work, performed largely by women. Improved and specific training delivers symbolic benefits, as it recognises the care work skills required from EPWP-SS participants. This recognition confers dignity and gravitas to a traditionally gendered and undervalued area of work. Changes in legislation have sought to define minimum stipends, working hours and leave days, though levels of compliance remain low (Vaughan, 2016). The professionalisation of the care work skill-set via ECD training offers participants a sense of dignity and improved sense of self-worth (EPRI, 2015), and is thus a small step towards transformative forms of social protection (Sabates-Wheeler and Roelen, 2011).

However, both the design and the implementation of the EPWP-SS raise important concerns from a transformative perspective. Firstly, some have argued that the inclusion of the social sector in the EPWP is opportunistic (Budlender, 2009), as many women were already doing HCBC and ECD work, and that the deepening of caring skills among women will not challenge traditional gender relations (Parenzee and Budlender, 2015).

Furthermore, the lower stipends in sectors dominated by women suggests that, just as care work, which is highly gendered, is considered of low value in the broader economy, so it is devalued and poorly recognised in the EPWP. This is often to do with the ill-informed assumption that care work is unskilled (van der Westhuizen, 2015). Therefore the poor working conditions and remuneration levels have served to entrench women's exploitation and institutionalise the undervaluation of care work. Truly recognising the contribution of this sector would require the provision of permanent jobs at decent wages rather than the inclusion of this work in the EPWP.

Overall, the linking of job creation needs to service delivery needs is a commendable policy innovation, with great potential for an integrated approach to women's reproductive and productive roles. Yet, several design, institutional 
and implementation factors hinder the transformative potential of the EPWPSS, particularly for women. The lack of synergy across interventions and the underfunding of ECD services also limits the transformative potential of the EPWP-SS.

\section{Towards a synergistic approach to social security and gender}

We conclude with a reflection on what lessons can be learned that are relevant to other low- and middle-income countries. First, we note that social assistance has had a significant redistributive effect, with high returns to investment that have helped to narrow the gender poverty gap. The sustained and well documented impacts of the CSG over two decades are testament to the role that a relatively small, well-targeted transfer, incrementally expanded and now delivered at scale, has played in reducing the effects of poverty and unemployment, especially for women.

In a context of stagnated economic and employment growth, which significantly disadvantages women, the South African case study shows that the extension of insurance and public employment has acknowledged the gendered nature of social provision. The instruments have potential but enormous challenges in their realisation. Social insurance in South Africa remains rigid and underdeveloped. Public employment programmes have been considerably scaled up and have injected small amounts of cash into large numbers of poor households. However, institutional structures, administrative weaknesses and weak monitoring systems have limited their ability to produce and conclusively show positive outcomes for women. Research funding and advocacy to inform further analysis are needed to bring a social justice and gender-sensitive lens to the analysis of under-reported social security instruments.

From a transformative perspective, the social security programmes have made contributions to the recognition and dignity of women, by acknowledging their roles in private and public spheres, by increasing the visibility of care work and by providing important material relief for households as well as increased opportunities for women to engage in economic activities, resulting in improved confidence and skills. However, these mechanisms have concurrently reinforced rather than relieved women's social reproductive responsibilities and buttressed assumptions about the type of work (and remuneration levels) appropriate for women in the labour market. The analysis has highlighted the structural and cultural challenges to redistributing care responsibilities in more equitable ways. Across the board, the surveyed social security instruments have struggled to facilitate the economic inclusion of women while recognising, valuing and redistributing unpaid care and domestic work.

Finally, cognisant of these challenges, it is important to consider which linkages between social security instruments and across other redistributive 
interventions (including basic, social and health services) can contribute towards the realisation of a comprehensive social security framework. In such a framework, each programme acts as a component of a system that supports women across lifecycle stages (childhood, job-seeking, employment, pregnancy, child-bearing and child-rearing, retirement); across multiple roles (productive and reproductive) and across employment status (unemployed, informal sectors, formal sectors, full-time/part-time). Examples of such strategies range from increasing access to quality child-care services to smoothing access to other available welfare services (including parenting support and mental health), as well as access to basic education and health services (including water, sanitation, electricity, nutrition and internet). The well-established networks of social security access points would be well placed to promote such linkages. Gendersensitive marketing of the CSG programme to advocate the engagement of men in care work could serve to counter societal norms around gender divisions of labour within the home (Khan, 2018, forthcoming). Given the evidence that the CSG can assist with job searches, linkages between the CSG and economic empowerment programmes could be developed, together with initiatives to increase compliance and extend social insurance to self-employed and informally employed workers. Examples from other countries demonstrate that childcare policy, negotiated between private and public stakeholders, is crucial for re-orienting welfare policy in a gender-sensitive direction (Yerkes, 2014). While the CSG, EPWP-SS and UIF are all core features of a relatively generous social protection landscape, there is scope going forward for continued efforts to design and implement synergies between social assistance, social insurance, public employment schemes and other social protection measures, in order to overcome cultural barriers, system failures and unemployment insecurity for the achievement of gender redistributive and transformative outcomes.

\section{References}

Antonopoulos, R. (2009), Promoting gender equality through stimulus packages and public job creation: lessons learned from South Africa's EPWP programme. Annandale-on-Hudson.

Bhorat, H., Goga, S. and Tseng, D. (2013a), Unemployment Insurance in South Africa. A descriptive overview of claimants and claims. Africa Growth Initiative Working Paper 8. Washington, DC: Brookings Institution.

Bhorat, H., van der Westhuizen, C. and Tseng, D. (2013b), Changes in Income Poverty and Inequality using Household Income Data: 1995 - 2010. Cape Town: Development Policy Research Unit, School of Economics, University of Cape Town.

Boswell, R. and Boswell, B. (2011), Motherhood deterred: Access to maternity benefits in South Africa. Agenda: Empowering women for gender equity, 23(82), 76-85.

Brockerhoff, S. (2013), Monitoring the Progressive Realisation of Socio-Economic Rights: A Review of the Development of Social Security Policy in South Africa. Johannesburg: Studies in Poverty and Inequality Institute (SPII).

Budlender, D. (2009), Towards Minimum Wages and Employment Conditions for the Expanded Public Works Programme Phase II. Report prepared for Shisaka Development Management Services by Community Agency for Social Enquiry. 
Butler, R. and Cartwright, K. (2016), Substitution and Displacement in the EPWP In A. Vaughan (Ed.), Our Expanded Public Works Programme. Reflections on over a decade (pp. 89-104), Johannesburg: South African Cities Network.

Delany, A., Ismail, Z., Graham, L. and Ramkisson, Y. (2008), Review of the Child Support Grant. Uses, Implementation and Obstacles. Johannesburg: Community Agency for Social Enquiry.

Department of Labour. (2016), Unemployment Insurance Amendment Act 10 of 2016. Pretoria: Department of Labour.

Devereux, S., Adato, M., Sabates-Wheeler, R., McConnell, J. and Becker, E. (2011), Child Support Grant Evaluation 2010: Qualitative Research Report. Pretoria, South Africa: Department of Social Development.

Devereux, S. and McGregor, J. (2014), Transforming Social Protection: Social Justice and Human Wellbeing. European Journal of Development Research, 26, 296-310.

Dinkelman, T., Ranchhod, V. and Hofmeyr, C. (2014), Enforcement and compliance: the case of minimum wages and mandatory contracts for domestic workers. Econ3x3, April 2014.

EPRI. (2015), Implementation Evaluation of EPWP in the Social Sector: Phase Two (2009/10 2013/14). Pretoria: EPRI.

Eyal, K. and Woolard, I. (2011), Female Labour Force Participation and South Africa's Child Support Grant. Paper presented at the CSAE 25th Anniversary Conference 2011: Economic Development in Africa. March 8, 2011. http://www.csae.ox.ac.uk/conferences/ 2011-EDiA/papers/467-Eyal.pdf

Fraser, N. (1995), From Redistribution to Recognition? Dilemmas of Justice in a 'Post-Socialist' Age. New Left Review, I/212.

Fultz, E. and Francis, J. (2013), Cash transfer programmes, poverty reduction and empowerment of women: A comparative analysis. Working Paper 4 / 2013. Geneva: ILO.

Gordon, S., Roberts, B. and Struwig, J. (2012), Shouldering the burden: gender attitudes towards balancing work and family. Pretoria: Democracy, Governance and Service Delivery programme, HSRC.

Hochfeld, T. and Plagerson, S. (2011), Dignity and stigma among South African female cash transfer recipients. IDS Bulletin, 42(6), 53-59.

Hochfeld, T. and Plagerson, S. (2017), A Micro-Analysis of Social Justice and the Child Support Grant. In L. Patel \& M. Ulriksen (Eds.), Learning from below: citizens, community and state action for development. A collection of community based studies in Doornkop, Soweto (pp. 46-64). Pretoria: HSRC.

Holmes, R. and Jones, N. (2013), Gender and social protection in the developing world. London: Zed Books.

ILO. (2017), World social protection report 2017. Geneva: International Labour Organization.

Inchauste, G., Lustig, N., Maboshe, M., Purfield, C. and Woolard, W. (2015), The Distributional Impact of Fiscal Policy in South Africa. Policy Research Working Paper 7194. Washington, DC: World Bank.

Jacobs, P., Baiphethi, M., Ngcobo, N. and Hart, T. (2010), The potential of social grants expenditure to promote local economic development and job creation. Pretoria, South Africa: Centre for Poverty, Employment and Growth. Human Sciences Research Council.

Khan, Z. (2018, forthcoming), Men and the Child Support Grant: Gender, Care and Child Wellbeing (doctoral thesis). Johannesburg: University of Johannesburg.

Leibbrandt, M., Lilenstein, K., Shenker, C. and Woolard, I. (2013), The influence of social transfers on labour supply: A South African and international review. A Southern Africa Labour and Development Research Unit Working Paper Number 112. Cape Town SALDRU, University of Cape Town.

Lund, F. (2008), Changing social policy. The Child Support Grant in South Africa. Cape Town: Human Sciences Research Council.

Luttrell, C. and Moser, C. (2004), Gender and social protection. London: Overseas Development Institute. 
Mahlakoana, T. (2017), Government increases wages of EPWP workers to R88 a day, Business Day, 31 October 2017 https://www.businesslive.co.za/bd/national/2017-10-31government-increases-wages-of-epwp-workers-to-r88-a-day/.

Makiwane, M. (2010), The Child Support Grant and teenage childbearing in South Africa. Development Southern Africa, 27(2), 193-204.

Malherbe, K. (2013), Implementing domestic workers' social security 117 rights in a framework of transformative constitutionalism In D. Du Toit (Ed.), Explited, undervalued - and essential: domestic workers and the realisation of their rights. Pretoria: Pretoria University Law Press.

McCord, A. (2012), Public Works and Social Protection in Sub-Saharan Africa. Cape Town: UCT Press.

Meth, C. (2011), Employer of Last Resort? South Africa's Expanded Public Works Programme (EPWP). A Southern Africa Labour and Development Research Unit Working Paper Number 58. Cape Town: SALDRU, University of Cape Town.

Mokomane, Z. (2011), Work-family balance: Overview of policies in developing countries. Paper presented at the Assessing family policies: Confronting family poverty and social exclusion \& Ensuring work-family balance, New York.

Molyneux, M. (2007), Change and Continuity in Social Protection in Latin America. Mothers at the Service of the State? Geneva: UNRISD.

Molyneux, M., Jones, N. and Samuels, F. (2016), Can Cash Transfers have Transformative Effects?' Introduction to Special Issue on Social Protection. Journal of Development Studies, $52(8)$.

Mpedi, L. and Fourie, E. (2008), Unemployment protection in South Africa. In M. Olivier and S. Kuhnle (Eds.), Norms and institutional design. Social security in Norway and South Africa. Stellenbosch: Sun Press.

NPC. (2011), National Development Plan 2030: our future make it work. Pretoria: National Planning Commission.

Parenzee, P. and Budlender, D. (2015), Introduction: A Gender Perspective on South Africa's Expanded Public Works Programme. In P. Parenzee and D. Budlender (Eds.), Who Cares? South Africa's Expanded Public Works Programme in the Social Sector and its Impact on Women. Cape Town: Heinrich Boll.

Patel, L. (2017), The Child Support Grant in South Africa: gender, care and social investment. In J. Midgley, E. Dahl and A. Wright (Eds.), Social Investment and Social Welfare: International and Critical Perspectives: Edward Elgar.

Patel, L. (2018, forthcoming), Gender: Toward gender equality and poverty reduction. In J. Midgley, R. Surender and L. Alfers (Eds.), Handbook of social policy and development: Edward Elgar.

Patel, L. and Hochfeld, T. (2011), It buys food but does it change gender relations? Child Support Grants in Soweto, South Africa. Gender and Development, 19(2), 229-240.

Patel, L., Knijn, G. and Van Wel, F. (2015), Child Support Grants in South Africa: A Pathway to Women's Empowerment and Child Well-being? Journal of Social Policy, 44(2), 377-397.

Patel, L., Knijn, T., Gorman-Smith, D., Hochfeld, T., Isserow, M., Garthe, R., . . Kgaphola, I. (2017), Family Contexts, Child Support Grants and Child Well-Being in South Africa. Retrieved from Johannesburg:

Plagerson, S. and Ulriksen, M. (2015), Cash transfer programmes, poverty reduction and economic empowerment of women in South Africa. GED Working Paper no. 4/2015. Geneva: Gender, Equality and Diversity Branch, Conditions of Work and Equality Department \& Social Protection Department, International Labour Office.

Posel, D. and Rogan, M. (2012), Gendered Trends in Poverty in the Post-Apartheid Period, 1997 - 2006. Development Southern Africa, 29(1), 96-113.

R.S.A. (1996), Constitution of the Republic of Africa. No 108 of 1996. Pretoria: Republic of South Africa.

R.S.A. (2015), Unemployment Insurance Fund Annual Report 2014/2015. Pretoria: Department of Labour. Accessed on 27 October 2016 http://www.labour.gov.za/DOL/downloads/ 
documents/annual-reports/unemployment-insurance-fund/2015/uifannualreport2015. pdf

R.S.A. (2017), Unemployment Insurance Fund Annual Report 2016/2017. Pretoria: Department of Labour.

Razavi, S. (2007), The Political and Social Economy of Care in a Development Context Conceptual Issues, Research Questions and Policy Options Geneva: UNRISD.

Razavi, S. (2011), Rethinking care in a development context. Devevelopment and Change, 42(4), 873-903.

Razavi, S. and Staab, S. (2012), Introduction: Global Variations in the Political and Social Economy of Care: Worlds Apart?. In S. Razavi and S. Staab (Eds.), Global Variations in the Political and Social Economy of Care: Worlds Apart. London: Routledge.

Rosenberg, M., Pettifor, A., Nguyen, N., Westreich, D., Bor, J., Bärnighausen, T. and Kahn, K. (2015), Relationship between Receipt of a Social Protection Grant for a Child and Second Pregnancy Rates among South African Women: A Cohort Study. PLoS ONE, 10(9), https://doi.org/10.1371/journal.pone.0137352.

Sabates-Wheeler, R. and Roelen, K. (2011), Transformative social protection programming for children and their carers: a gender perspective. Gender and Development, 19(2), 179-194.

SASSA. (2014), SOCPEN database. Pretoria: South African Social Security Agency.

SASSA. (2017), Fact sheet: Issue no. 8 of 2017 - 31 August 2017. Pretoria: South African Social Security Agency.

Skosana, N. (2013), Social Sector EPWP. Presented at workshop on Reflections on the Case for Expanded Public Works Programme (EPWP) Extension Workers in the Social Sector, Pretoria, 31 October 2013.

SSA. (2018), Quarterly Labour Force Survey. Quarter 4, 2017. Pretoria: Statistics South Africa.

Surender, R., Noble, M., Wright, G. and Ntshongwana, P. (2010), Social Assistance and Dependency in South Africa: An Analysis of Attitudes to Paid Work and Social Grants. Journal of Social Policy, 39(2), 203221.

UN. (2015), Transforming Our World: The 2030 Agenda for Sustainable Development. https://sustainabledevelopment.un.org/post2015/transformingourworld New York: United Nations.

UNRISD. (2016), UNRISD Flagship Report 2016. Policy Innovations for transformative change. Implementing the 2030 Agenda for Sustainable Development. Geneva: UNRISD.

van der Westhuizen, C. (2015), Setting the scene: public works employment from the RDP to the NDP. In P. Parenzee and D. Budlender (Eds.), Who cares? South Africa's Expanded Public Wiorks in the social sector and its impatc on women. Cape Town: Heinrich Boll Foundation Southern Africa.

Vaughan, A. (2016), Our Expanded Public Works Programme reflections on over a decade Pretoria: Department of Public Works, Government Printer.

Vetten, L. (2015), Who Cares? Post-Rape Services and the Expanded public Works Programme in South Africa. In P. Parenzee and D. Budlender (Eds.), Who Cares? South Africa's Expanded Public Works Programme in the Social Sector and its Impact on Women (pp. 60-76), Cape Town: Heinrich Böll Stiftung.

Vetten, L. (2016), Unintended complicities: preventing violence against women in South Africa. Gender \& Development, 24(2), 291-306.

Williams, M. (2007), The Social and Economic Impacts of South Africa's Child Support Grant. Cape Town, South Africa: Economic Policy Research Institute.

Woolard, I., Harttgen, K. and Klasen, S. (2011), The history and impact of social security in South Africa: experiences and lessons. Canadian Journal of Development Studies/Revue canadienne d'études du développement, 32(4), 357-380.

Yerkes, M. (2014), Collective protection for new social risks: childcare and the Dutch welfare state. Journal of Social Policy, 43(4), 811-828. 